\title{
EDITORIAL
}

\section{academic profile-building in a changing higher education system}

$F^{2}$ or the European Consortium for Political Research (ECPR) (and therefore for this journal), there are few aspects of the political science profession more important than the opportunities for young political scientists to forge an academic career. It is important that we constantly monitor the situation of young political scientists, as without their future successes, the profession faces a dismal future. For this reason, we regularly publish papers on diverse themes of relevance to younger members of the profession, and in 2006 hosted an important symposium on 'Young people in the European politicalscience profession' (Rhodes, 2006).

In this issue, we host a symposium guest-edited by Irina Stefuriuc, which focuses on young political scientists building an academic profile in the context of a European political-science profession that is undergoing a veritable transformation. The authors in this symposium emphasise the manner in which the 'skill set' needed by young political scientists has changed and expanded in the past 30 years, with the consequence that the Ph.D., once viewed, in Peter Mair's words, as 'a defining component within an academic career has now become simply a necessary professional qualification - and researchers need to see it in these terms' (Mair, 2009: 143). Researchers are now required to be methodologically highly (and, through Ph.D. programmes, formally) trained; to have a good publications record early on; to have a broad grounding in political science and a wider knowledge beyond the discipline; to have started generating research income; to have good teaching experience, and to be adept at administrative/managerial tasks. Moreover, the constant increase in the number of Ph.D.s awarded means that it is no longer just the award itself, which is important, but the time taken to complete it. As Jan Erk (2009: 157) comments, 'A doctoral thesis that has taken an inordinate amount of time to complete is interpreted - rightly or wrongly - as a sign of inefficiency'. In addition, a combination of European integration (standardisation) and the evolution of quantitative performance measures have increased the cross-national competitiveness of the profession. And, despite the ongoing transformation in the provision of formal doctoral training, young European political scientists find themselves facing increased levels of competition for jobs in Europe from Americans who, as Erin Jenne (2009) points out, have various incentives to enter the European job market.

Faced with these challenges, the authors in this symposium provide a wealth of advice to graduate students embarking on a political science career in Europe. Indeed, the advice comes from a much broader source than just the authors themselves, as Lori Thorlakson's (2009) paper is based on interviews with over thirty political scientists, established in their fields, who were all asked the same 
question: knowing what they know now, what advice would they give to someone just starting out in the job? We hope, therefore, that young political scientists will find this symposium a useful resource. We hope, too, that it will remind more established political scientists how their profession has changed in the past 30 years and how, as a consequence, young academics are confronted with a different set of challenges to those which established scholars faced in 'their day'.

If European political scientists have a concern that tends to distinguish them from political scientists elsewhere, then it is their concern for the 'European project' - the attempt to integrate Europe economically, socially and politically - which has ramifications not only for research, but also for the teaching and professional concerns of political scientists. In this context, we are delighted to publish revised versions of an exchange between Paul Magnette (2009) and Maurizio Ferrera (2009), which originally appeared in Italian. We have also given an added twist to the exchange by soliciting a further contribution from Vivien Schmidt (2009), thus creating a fascinating debate on the fragility and liberality of the European project, and what needs to be done to ensure its best future.

The research paper by Jan Van Deth (2009) on the 'Good European Citizen' is pertinent in this context. Exploring the types of orientation and behaviour which EU policy-makers, civil-society bodies and EU citizens (all as separate categories) consider desirable for the 'good citizen', and finding considerable differences in these, he is able to explain how these differences can affect the efforts to develop more democratic decision- making processes and active citizenship in the European Union, or, rather, how fruitless some of the attempts may be to promote greater citizenship until these basic differences are understood first.

Of course, if the European political science profession has one important task with regard to the European Union, it is to provide a better understanding of it to those whom they educate. This is not an insignificant task in view of the finding amongst many political scientists that undergraduate students find the subject dry and uninteresting. In this light, the paper in the Teaching and Training section by Christian Kaunert (2009) is very pertinent, because it aims to demonstrate that, 'contrary to a commonly held view, it is possible to teach the European Union in a way that makes students enthusiastic about the subject'. Based on his personal experience in teaching in a UK university, Kaunert shows how using a problem-based learning approach through a module which simulates the practices and dilemmas of the European Union, political scientists can produce a much richer and more satisfying learning experience for students.

Finally, in the section on the Profession, we publish two papers on national situations, the first on the extent of gender inequalities in the Spanish university sector (Elizondo et al, 2009), and the second on the state of International Relations as a discipline, or sub-discipline, in France (Chillaud, 2009). Both are hardhitting and challenging, if not provocative, in their conclusions, and demand further analysis and contributions - which we hope readers will provide in the future.

martin j. bull and james I. newell University of Salford

\section{References}

Chi, M. (2009) 'International relations in France: The "Usual Suspects" in a French scientific field of study?' European Political Science 8(2): 239-253.

Elizondo, A., Martínez, E., Novo, A. and Silvestre, M. (2009) 'Women in political science: Figures for Spanish universities', European Political Science 8(2): 225-238. 
Erk, J. (2009) 'The changing European profession of political science', European Political Science 8(2): 151-161.

Ferrera, M. (2009) 'A less fragile, if more liberal Europe', European Political Science 8(2): 201-211.

Jenne, E. (2009) 'Preparing for an academic career in Europe: The perspective of a North American', European Political Science 8(2): 168-174.

Kaunert, C. (2009) 'The European union simulation: From problem-based learning (PBL) to student interest', European Political Science 8(2): 254-265.

Magnette, P. (2009) 'The fragility of liberal Europe', European Political Science 8(2): 190-200.

Mair, P. (2009) 'The way we work now', European Political Science 8(2): 143-150.

Rhodes, M. (2006) 'Young people in the political science profession', European Political Science 5(3): 232-234.

Schmidt, V. (2009) 'Envisioning a less Fragile, more liberal Europe', European Political Science 8(2): 212-224.

Thorlakson, L. (2009) 'Collected wisdom: Advice to new entrants to the profession', European Political Science 8(2): 162-167.

Van Deth, J. (2009) 'The "Good European Citizen": Congruence and consequences of different points of view', European Political Science 8(2): 175-189.

doi:10.1057/eps.2009.10 